\title{
A practical and efficient approach to imidazo[1,2-a]pyridine- fused isoquinolines through the post-GBB transformation strategy
}

\author{
Taofeng Shao, Zhiming Gong, Tianyi Su, Wei Hao and Chao Che*
}

\author{
Full Research Paper \\ Address: \\ Laboratory of Chemical Genomics, Engineering Laboratory for Chiral \\ Drug Synthesis, School of Chemical Biology and Biotechnology, \\ Peking University Shenzhen Graduate School, Shenzhen 518055, \\ China \\ Email: \\ Chao Che* - chec@pkusz.edu.cn \\ * Corresponding author \\ Keywords: \\ Groebke-Blackburn-Bienaymé reaction; imidazo[1,2-a]pyridines; \\ isoquinolines; multicomponent reaction; Ugi reaction
}

\author{
Beilstein J. Org. Chem. 2017, 13, 817-824. \\ doi:10.3762/bjoc. 13.82 \\ Received: 06 March 2017 \\ Accepted: 13 April 2017 \\ Published: 04 May 2017 \\ Associate Editor: D. Spring \\ (C) 2017 Shao et al.; licensee Beilstein-Institut. \\ License and terms: see end of document.
}

\begin{abstract}
Diversity-oriented synthesis of the biologically intriguing imidazo[1,2- $a$ ]pyridine-fused isoquinoline systems from readily available starting materials was achieved through the Groebke-Blackburn-Bienaymé reaction followed by a gold-catalyzed cyclization strategy. The synthetic approach is characterized by mild reaction conditions and a broad substrate scope, allowing for the rapid construction of structurally complex and diverse heterocycles in moderate to good yields.
\end{abstract}

\section{Introduction}

Imidazo[1,2- $a]$ pyridines have been reported to display a wide range of biological activities [1-5], and these skeletons are found in various clinical drugs such as zolpidem (I), alpidem (II), and olprinone (III), which were approved for the treatment of insomnia, anxiety and acute heart failure, respectively (Figure 1) [6]. Furthermore, the isoquinoline motif represents a privileged medicinal skeleton widely found in a number of natural alkaloids and pharmaceutically active compounds [7]. Some of them exhibit diversified biological properties, including anti-inflammatory [8], antibacterial [9], antiviral [10], and antitumor activities [11]. For example, the natural alkaloids berberine (IV) and narciclasine (V) possess antiplasmodial and antiviral activity, respectively $[12,13]$. Indotecan (VI) and its analog idimitecan (VII) were identified as topoisomerase I inhibitors, and were promoted into phase I clinical trials [14].

Multicomponent reactions (MCRs) [15-19], comprising three or more components, provide straightforward approaches to a wide range of heterocycles through the formation of various bonds in a one-pot process. These reactions not only greatly accelerate chemical syntheses [20], but also allow access to diverse chemical structures [21] from readily accessible building blocks. In 


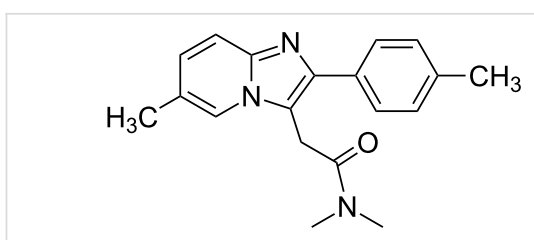

zolpidem (I)

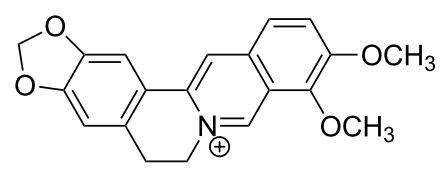

berberine (IV)<smiles>CCCN(CCC)C(=O)Cc1c(-c2ccc(Cl)cc2)nc2ccc(Cl)cn12</smiles>

alpidem (II)<smiles>C[C@@]12NC(=O)c3c(cc4c(c3O)OCO4)C1=C[C@H](O)[C@@H](O)[C@H]2O</smiles>

narciclasine (V)<smiles>Cc1[nH]c(=O)c(C#N)cc1-c1ccc2nccn2c1</smiles>

olprinone (III)<smiles></smiles>

indotecan (VI): $\mathrm{R}$ = morpholin-4-yl idimitecan (VII): $\mathrm{R}=$ imidazol-1-yl

Figure 1: Representative bioactive imidazo[1,2-a]pyridine and isoquinoline-containing derivatives.

the past decades, considerable efforts have been made towards the development of new MCRs and their application to the diversity-oriented synthesis of biologically relevant molecules for drug discovery [22-27].

The Ugi reaction [28], an elegant pioneer of a multicomponent reaction, represents a powerful synthetic tool to assemble versatile peptide-like compounds. It has found many applications in the facile synthesis of natural products and biologically interesting molecules [29,30]. Although the Ugi-4CR generates linear $\alpha$-acylamino-amides, a wide range of heterocycles are accessible through the combination with other transformations (posttransformation strategy) [31]. For example, the Ugi/Diels-Alder process leads to the formation of benzofurans and indoles [32] as well as to structurally complex polycyclic ring systems [33]; an Ugi/aza-Wittig process allowed for the synthesis of 2,5disubstituted 1,3,4-oxadiazoles [34]; the Ugi/Pictet-Spengler sequence provided a rapid and efficient approach to polycyclic natural product-like alkaloids [35]. Accordingly, the combination of the Ugi reaction with other transformations proved to be powerful strategies for the efficient synthesis of novel heterocycles. In 1998, the Groebke-Blackburn-Bienaymé (GBB) reaction, an Ugi-3CR variant was discovered by three groups independently [36-38]. The GBB reaction of an amidine, an aldehyde and an isocyanide proceeds through the isocyanide-involving formal [4+1] cycloaddition [39] affording the biologically important imidazo[1,2-a]pyridine scaffold. Due to the atom and step economy, high efficiency and intriguing biological profiles of the products, the GBB reaction has attracted broad attention in the field of organic synthesis [40-42]. In order to expand the structural diversity of GBB products, further investigation of GBB-based synthetic strategies remains highly desirable.
In continuation of our research on the development of MCR strategies for the rapid library synthesis of biologically interesting heterocycles [43-47], we were interested in a practical synthetic strategy towards imidazo[1,2- $a$ ]pyridine-fused isoquinoline systems. We believe that this type of polycyclic systems may have interesting biological profiles [48]. Herein, we report our recent efforts on the development of a post-GBB transformation strategy for the concise synthesis of diverse imidazo[1,2-a]pyridine-fused isoquinoline systems.

\section{Results and Discussion}

From a design perspective, we envisioned that the imidazo[1,2a]pyridine-fused isoquinoline $\mathbf{6 a}[49,50]$ could be constructed through a GBB reaction/cyclization strategy (Scheme 1). The intermediate GBB product $\mathbf{4 a}$ could be constructed starting from 2-ethynylbenzaldehyde (2a) through an imine formation/ formal $[4+1]$ cycloaddition/[1,3]-H shift. The so obtained GBB product imidazo[1,2-a]pyridine $\mathbf{4 a}$ bearing an amino group and an acetylene unit may then undergo a sequential 6-exo-dig cyclization/retro-ene reaction to form the desired imidazo[1,2-a]pyridine-fused isoquinoline 6a. The cyclization reaction could be realized with the aid of silver or gold catalysts $[51,52]$.

With this idea in mind, we commenced our studies by investigating the GBB reaction of 2-aminopyridine (1a), 2-ethynylbenzaldehyde (2a) and tert-butylisocyanide (3). The GBB reaction proceeded smoothly in $\mathrm{MeOH}$ in the presence of catalytic PTSA or $\mathrm{HClO}_{4}$ at room temperature to afford imidazo[1,2a]pyridine $4 \mathbf{a}$ in $90 \%$ yield, and the cyclized product $6 \mathbf{a}$ was not detected under these mild conditions. Subsequent heating of $\mathbf{4 a}$ in refluxing 1,4-dioxane or toluene failed to deliver the expected product $\mathbf{6 a}$, even under acidic or basic conditions. 


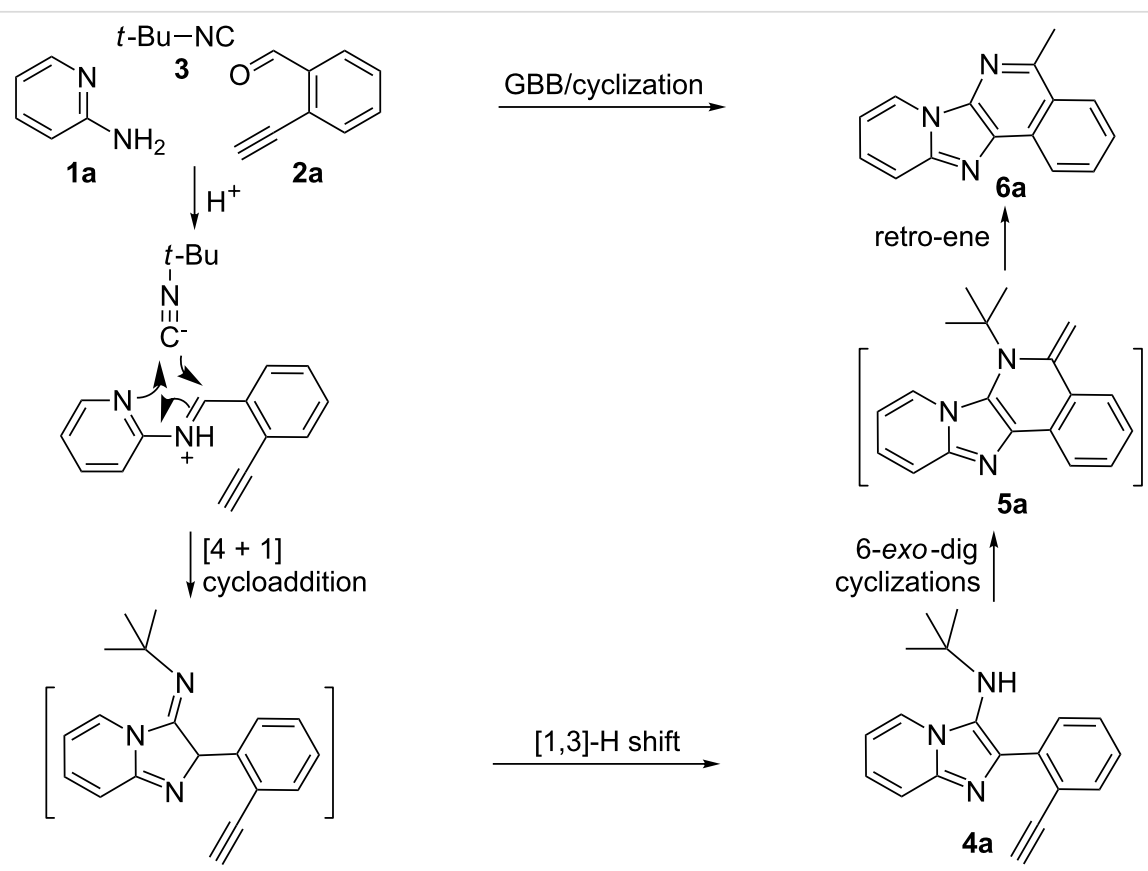

Scheme 1: GBB-based MCR strategy for the imidazo[1,2-a]pyridine-fused isoquinoline derivatives.

Then, we turned to Ag and Au catalysts and investigated the metal-catalyzed intramolecular cyclization reaction of $\mathbf{4 a}$ and the results are collected in Table 1. First, we investigated AgOTf as the catalyst, which afforded the cyclized product $\mathbf{6 a}$ in $12 \%$ yield in refluxing $\mathrm{CH}_{2} \mathrm{Cl}_{2}$ in the presence of $10 \mathrm{~mol} \%$ of catalyst. The yield was increased to $45 \%$ when replacing $\mathrm{CH}_{2} \mathrm{Cl}_{2}$ with $\mathrm{CHCl}_{3}$, whereas only a trace amount of the desired product was obtained in refluxing $\mathrm{CH}_{3} \mathrm{CN}$ or 1,4-dioxane (Table 1, entries 1-4). It revealed that the solvent plays a key role in this cyclization reaction. For comparison, we tested also $\mathrm{AgSbF}_{6}$ as the catalyst and it was found to be less effective than AgOTf (Table 1, entry 5). To improve the reaction efficiency, we next evaluated the cyclization reaction in refluxing $\mathrm{CHCl}_{3}$ in the presence of a range of $\mathrm{Au}$ catalysts. Although almost no reaction took place with $\mathrm{Au}\left(\mathrm{PPh}_{3}\right) \mathrm{Cl}$ as the catalyst, the use of $\mathrm{Au}\left(\mathrm{PPh}_{3}\right) \mathrm{NTf}_{2}$ resulted in a satisfactory yield $(70 \%)$ of the product (Table 1, entries 6-9). Motivated by this result, other $\mathrm{Au}$ catalysts were further surveyed, and $\mathrm{Au}(\mathrm{JohnPhos}) \mathrm{Cl}$ was found to be the most efficient, delivering $6 \mathbf{a}$ in $78 \%$ yield (Table 1, entries 10-14). Next, the effect of the solvent on the reaction was tested and replacement of $\mathrm{CHCl}_{3}$ with $\mathrm{CH}_{3} \mathrm{CN}$ led to a slightly enhanced yield (83\%) (Table 1, entries 15 and 16). Additionally, in refluxing $\mathrm{CH}_{3} \mathrm{CN}$ no other $\mathrm{Au}$ catalysts afforded better results than $\mathrm{Au}(\mathrm{JohnPhos}) \mathrm{Cl}$ (Table 1, entries 17 and 18). Overall, the optimal conditions for the cyclization reaction are as follows: $\mathrm{Au}(\mathrm{JohnPhos}) \mathrm{Cl}(10 \mathrm{~mol} \%), \mathrm{CH}_{3} \mathrm{CN}$, reflux, $24 \mathrm{~h}$.

With the optimal conditions at hand, we then set out to explore the reaction scope for the library generation of structurally

\begin{tabular}{|c|c|c|c|}
\hline \multicolumn{2}{|c|}{$4 a \|$} & \multicolumn{2}{|r|}{$6 a$} \\
\hline Entry & Catalyst & Solvent & Yield $^{\mathrm{b}}(\%)$ \\
\hline 1 & AgOTf & $\mathrm{CH}_{2} \mathrm{Cl}_{2}$ & 12 \\
\hline 2 & AgOTf & $\mathrm{CHCl}_{3}$ & 45 \\
\hline 3 & AgOTf & $\mathrm{CH}_{3} \mathrm{CN}$ & trace \\
\hline 4 & AgOTf & dioxane & trace \\
\hline 5 & $\mathrm{AgSbF}_{6}$ & $\mathrm{CHCl}_{3}$ & 38 \\
\hline 6 & $\mathrm{Au}\left(\mathrm{PPh}_{3}\right) \mathrm{Cl}$ & $\mathrm{CHCl}_{3}$ & trace \\
\hline 7 & $\mathrm{Au}\left(\mathrm{PPh}_{3}\right) \mathrm{OTf}$ & $\mathrm{CHCl}_{3}$ & 42 \\
\hline 8 & $\mathrm{Au}\left(\mathrm{PPh}_{3}\right) \mathrm{SbF}_{6}$ & $\mathrm{CHCl}_{3}$ & 21 \\
\hline 9 & $\mathrm{Au}\left(\mathrm{PPh}_{3}\right) \mathrm{NTf}_{2}$ & $\mathrm{CHCl}_{3}$ & 70 \\
\hline 10 & $\mathrm{Au}_{2}(\mathrm{dppe})\left(\mathrm{SbF}_{6}\right)_{2}$ & $\mathrm{CHCl}_{3}$ & 51 \\
\hline 11 & $\mathrm{Au}_{2}($ binap $)\left(\mathrm{SbF}_{6}\right)_{2}$ & $\mathrm{CHCl}_{3}$ & 53 \\
\hline 12 & $\mathrm{Au}(\mathrm{JohnPhos}) \mathrm{Cl}$ & $\mathrm{CHCl}_{3}$ & 78 \\
\hline 13 & Au(JohnPhos)OTf & $\mathrm{CHCl}_{3}$ & 42 \\
\hline 14 & $\mathrm{Au}$ (JohnPhos)SbF 6 & $\mathrm{CHCl}_{3}$ & 74 \\
\hline 15 & $\mathrm{Au}(J o h n P h o s) \mathrm{Cl}$ & $\mathrm{CH}_{3} \mathrm{CN}$ & 83 \\
\hline 16 & $\mathrm{Au}(J o h n P h o s) \mathrm{Cl}$ & dioxane & 49 \\
\hline 17 & $\mathrm{Au}_{2}(\mathrm{dppe}) \mathrm{Cl}_{2}$ & $\mathrm{CH}_{3} \mathrm{CN}$ & 34 \\
\hline 18 & $\mathrm{Au}_{2}$ (binap) $\mathrm{Cl}_{2}$ & $\mathrm{CH}_{3} \mathrm{CN}$ & 42 \\
\hline
\end{tabular}

aGeneral conditions: substrate $4 \mathrm{a}(0.2 \mathrm{mmol})$, catalyst $(10 \mathrm{~mol} \%)$, solvent $(2 \mathrm{~mL})$ at reflux temperature for $24 \mathrm{~h}$. b Isolated yield. 
diverse imidazo[1,2- $a$ pyridine-fused isoquinolines and the results are collected in Table 2. Initially, several GBB adducts 4 were synthesized through GBB reaction of amidines $\mathbf{1}$, substituted 2-ethynylbenzaldehydes $\mathbf{2}$ and tert-butylisocyanide (3). Indeed, the acetylene group in the aldehyde component had no obvious steric effect on the efficiency of the GBB reaction affording the GBB product in good to excellent yields in most cases. On the other hand, the substituent ortho to the amino group in the amidine component had a negative effect on the GBB reaction efficiency due to steric hindrance (Table 2, entries 6, 11, 13 and 17).

Then, the newly generated GBB adducts $\mathbf{4 b}-\mathbf{s}$ were exposed to the established cyclization conditions to deliver the corresponding imidazo[1,2-a]pyridine-fused isoquinolines $\mathbf{6 b}-\mathbf{s}$ in moderate to good yields, and their structures were unambiguously

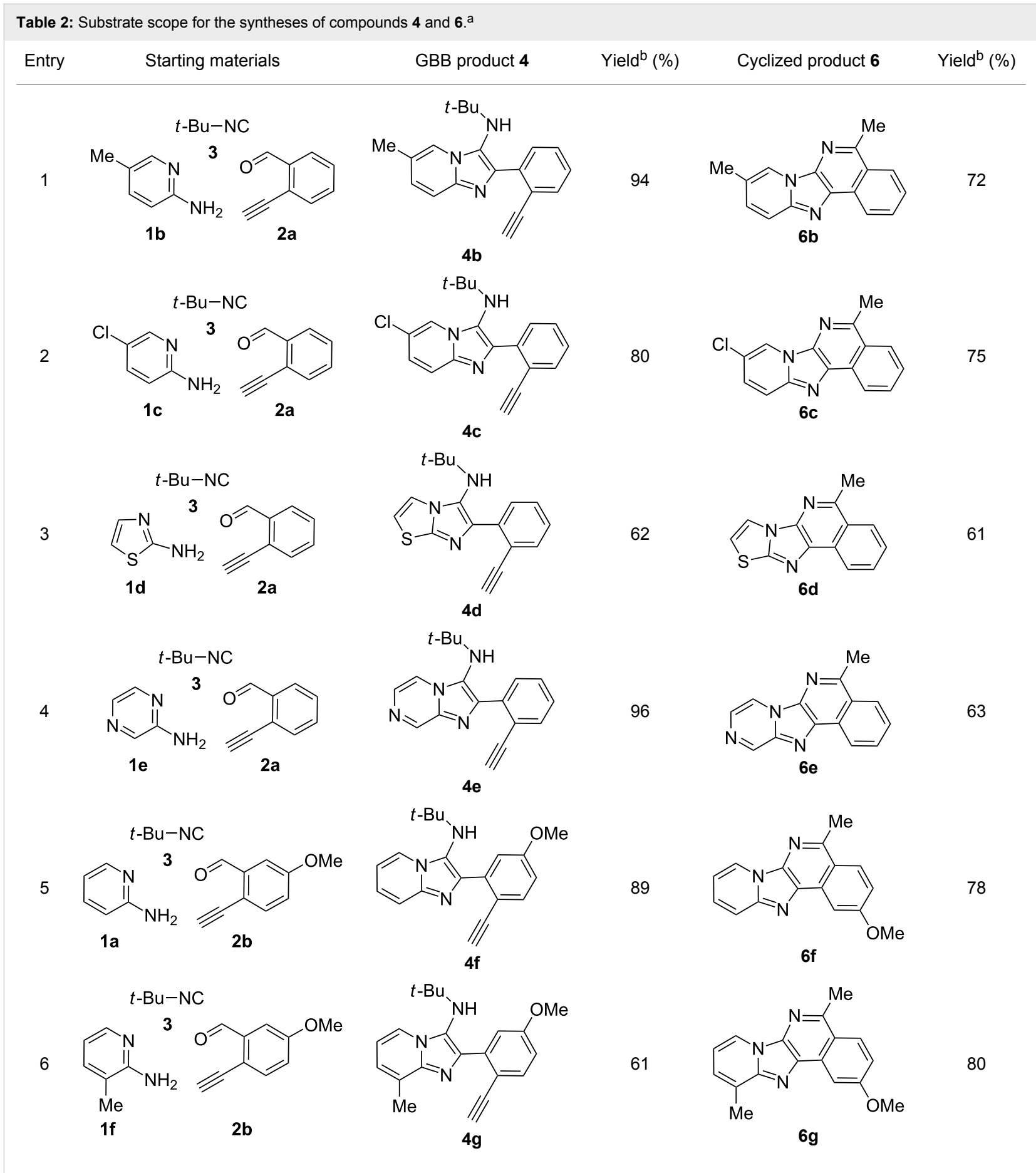


Table 2: Substrate scope for the syntheses of compounds 4 and $6 .^{a}$ (continued)<smiles>C#Cc1ccc(OC)cc1C=O</smiles>

$1 d$

2b<smiles>C#Cc1ccc(OC)cc1-c1nc2sccn2c1NC(=O)CC</smiles>

8<smiles>C#Cc1ccc(OC)cc1C=O</smiles>

$1 e$

$2 b$<smiles>C#Cc1ccc(OC)cc1-c1nc2cnccn2c1NC(=O)c1ccccc1</smiles><smiles>COc1ccc2c(C)nc3c(nc4sccn43)c2c1</smiles>

$6 h$<smiles>COc1ccc2c(C)nc3c(nc4cnccn43)c2c1</smiles>

88

$6 i$<smiles>Cc1ccc2c(c1)c(C)nc1c2nc2ccc(Br)cn21</smiles>

6j<smiles>Cc1ccc2c(c1)c(C)nc1c2nc2ccc(C)cn21</smiles>

87

49<smiles>Cc1ccc2c(c1)c(C)nc1c2nc2c(C)cccn21</smiles>

79

71<smiles>Cc1nc2c(nc3ccccn32)c2cc(Cl)ccc12</smiles>

48

47<smiles>Cc1nc2c(nc3c(C)cccn32)c2cc(Cl)ccc12</smiles>

55<smiles>Cc1nc2c(nc3sccn32)c2cc(Cl)ccc12</smiles>

60

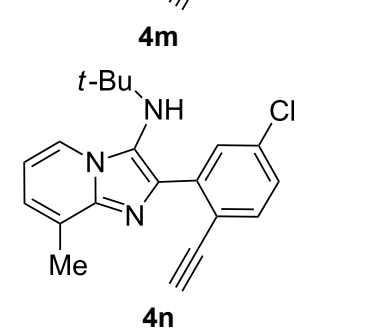

54

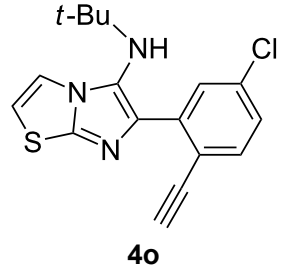

6 58 
Table 2: Substrate scope for the syntheses of compounds 4 and $6 .^{a}$ (continued)<smiles>C#Cc1ccc(Cl)cc1C=O</smiles>

$1 e$

2d<smiles>C#Cc1cc(F)ccc1C=O</smiles>

$1 \mathrm{~b}$ $t-\mathrm{Bu}-\mathrm{NC}$

17<smiles>C#Cc1cc(F)ccc1C=O</smiles>

t-Bu-NC<smiles>C#Cc1ccc(F)cc1C=O</smiles>

1d<smiles>C#Cc1ccc(Cl)cc1-c1nc2cnccn2c1NC(=O)C(C)(C)C</smiles>

$t-\mathrm{Bu}$,<smiles>C#Cc1cc(F)ccc1-c1nc2ccc(C)cn2c1N[Ga][Te]</smiles>

$4 q$<smiles>Cc1cccn2c(NC(=O)c3ccccc3)c(-c3ccc(F)cc3C#C[Ge])nc12</smiles>

$t-B u$

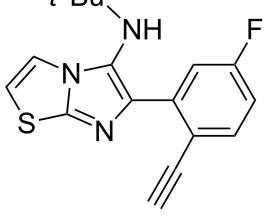

95<smiles>Cc1nc2c(nc3cnccn32)c2cc(Cl)ccc12</smiles>

$6 p$<smiles>Cc1ccc2nc3c4ccc(F)cc4c(C)nc3n2c1</smiles>

59

63<smiles>Cc1nc2c(nc3c(C)cccn32)c2ccc(F)cc12</smiles>

57

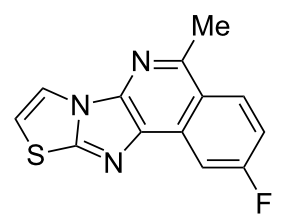

6s

${ }^{a}$ GBB reaction conditions: $1(0.5 \mathrm{mmol}), 2(0.5 \mathrm{mmol}), 3(0.6 \mathrm{mmol}), \mathrm{MeOH}(1 \mathrm{~mL})$; PTSA $(5 \%)$, room temperature, 12h; annulation conditions: substrate $4(0.2 \mathrm{mmol}), \mathrm{Au}(\mathrm{JohnPhos}) \mathrm{Cl}(10 \mathrm{~mol} \%), \mathrm{CH}_{3} \mathrm{CN}(2 \mathrm{~mL})$ at reflux temperature for $24 \mathrm{~h}$. blsolated yields.

confirmed by ${ }^{1} \mathrm{H}$ NMR, ${ }^{13} \mathrm{C}$ NMR, and HRMS analysis. Various functionalities related to the amidine and aldehyde components, including electron-donating methoxy and methyl groups or electron-withdrawing halides, were well tolerated. Generally, the substitution pattern of the amidine moiety had little effect on the Au-catalyzed annulation reaction, whereas neutral or electron-donating groups on the aldehyde moiety gave a higher yield in comparison with the electron-withdrawing halides. Notably, bromo-substituted substrates were also tolerated the reaction conditions, allowing for the further manipulation through various cross-coupling reaction (Table 2 , entry 9).

\section{Conclusion}

In conclusion, we have developed a practical and efficient synthetic approach to structurally diverse imidazo[1,2-a]pyridinefused isoquinolines with moderate to good yields through the GBB multicomponent reaction/Au-catalyzed cyclization strategy. The described method provides a new tool for a rapid compound library generation from readily accessible starting materials. Further, the protocol tolerates a broad substrate scope, which will make it attractive for the application in parallel synthesis and combinatorial chemistry.

\section{Experimental}

Typical procedure for the GBB multicomponent reaction. To a solution of 2-aminopyridine (1a, $0.5 \mathrm{mmol}$ ), 2-ethynylbenzaldehyde (2a, $0.5 \mathrm{mmol})$, and tert-butylisocyanide (3, $0.6 \mathrm{mmol})$ in $1 \mathrm{~mL}$ of methanol were added $p$-toluenesulfonic acid $(4.7 \mathrm{mg}, 0.025 \mathrm{mmol})$ and the reaction mixture was stirred at $\mathrm{rt}$ for $12 \mathrm{~h}$. The mixture was diluted with $15 \mathrm{~mL}$ of dichloromethane and washed successively with water $(10 \mathrm{~mL})$, saturated $\mathrm{NaHCO}_{3}$ solution $(10 \mathrm{~mL})$ and brine $(10 \mathrm{~mL})$. After drying over anhydrous $\mathrm{Na}_{2} \mathrm{SO}_{4}$, the mixture was concentrated under vacuum and the resulting residue was purified by flash chromatography (hexane/ethyl acetate $8: 1$ ) to afford GBB adduct $4 \mathbf{a}$ (90\% yield).

Typical procedure for the Au-catalyzed cyclization reaction. To a solution of the GBB adduct $4(0.2 \mathrm{mmol})$ in $2 \mathrm{~mL}$ of acetonitrile was added $\mathrm{Au}(\mathrm{JohnPhos}) \mathrm{Cl}(0.02 \mathrm{mmol})$ and the resulting mixture was stirred under inert atmosphere at reflux temper- 
ature for $24 \mathrm{~h}$. Then, the solvent was removed under vacuum and the residue purified by flash chromatography (hexane/ethyl acetate 5:1) to afford the desired product 6 .

\section{Supporting Information}

\section{Supporting Information File 1}

Characterization data for all compounds and copies of

NMR spectra for compounds $\mathbf{6 a}-\mathbf{s}$.

[http://www.beilstein-journals.org/bjoc/content/

supplementary/1860-5397-13-82-S1.pdf]

\section{Acknowledgements}

We thank the Shenzhen Basic Research Project (Grants No. JCYJ20140417144423193, and JSGG20140717102922014), the National Natural Science Foundation of China (Grant No. 21102006) and the Natural Science Foundation of Guangdong Province (Grant No. 2014A030312004) for financial support.

\section{References}

1. Tantry, S. J.; Markad, S. D.; Shinde, V.; Bhat, J.; Balakrishnan, G.; Gupta, A. K.; Ambady, A.; Raichurkar, A.; Kedari, C.; Sharma, S.; Mudugal, N. V.; Narayan, A.; Kumar, C. N. N.; Nanduri, R.; Bharath, S.; Reddy, J.; Panduga, V.; Prabhakar, K. R.; Kandaswamy, K.; Saralaya, R.; Kaur, P.; Dinesh, N.; Guptha, S.; Rich, K.; Murray, D.; Plant, H.; Preston, M.; Ashton, H.; Plant, D.; Walsh, J.; Alcock, P.; Naylor, K.; Collier, M.; Whiteaker, J.; McLaughlin, R. E.; Mallya, M.; Panda, M.; Rudrapatna, S.; Ramachandran, V.; Shandil, R.; Sambandamurthy, V. K.; Mdluli, K.; Cooper, C. B.; Rubin, H.; Yano, T.; Iyer, P.; Narayanan, S.; Kavanagh, S.; Mukherjee, K.; Balasubramanian, V.; Hosagrahara, V. P.; Solapure, S.; Ravishankar, S.; Hammed, P. S. J. Med. Chem. 2017, 60, 1379-1399. doi:10.1021/acs.jmedchem.6b01358

2. Shukla, N. M.; Salunke, D. B.; Yoo, E.; Mutz, C. A.; Balakrishna, R.; David, S. A. Bioorg. Med. Chem. 2012, 20, 5850-5863. doi:10.1016/j.bmc.2012.07.052

3. Hamdouchi, C.; de Blas, J.; del Prado, M.; Gruber, J.; Heinz, B. A.; Vance, L. J. Med. Chem. 1999, 42, 50-59. doi:10.1021/jm9810405

4. Frett, B.; McConnell, N.; Smith, C. C.; Wang, Y.; Shah, N. P.; Li, H.-y. Eur. J. Med. Chem. 2015, 94, 123-131. doi:10.1016/j.ejmech.2015.02.052

5. Bode, M. L.; Gravestock, D.; Moleele, S. S.; van der Westhuyzen, C. W.; Pelly, S. C.; Steenkamp, P. A.; Hoppe, H. C.; Khan, T.; Nkabinde, L. A. Bioorg. Med. Chem. 2011, 19, 4227-4237. doi:10.1016/j.bmc.2011.05.062

6. Enguehard-Gueiffier, C.; Gueiffier, A. Mini-Rev. Med. Chem. 2007, 7, 888-899. doi:10.2174/138955707781662645

7. Bentley, K. W. Nat. Prod. Rep. 1998, 15, 341-362. doi:10.1039/a815341y

8. Charpiot, B.; Bitsch, F.; Buchheit, K.-H.; Channez, P.; Mazzoni, L.; Mueller, T.; Vachier, I.; Naef, R. Bioorg. Med. Chem. 2001, 9, 1793-1805. doi:10.1016/S0968-0896(01)00077-3

9. Kim, S.-H.; Shin, D.-S.; Oh, M.-N.; Chung, S.-C.; Lee, J.-S.; Oh, K.-B. Biosci., Biotechnol., Biochem. 2004, 68, 421-424. doi:10.1271/bbb.68.421
10. Kartsev, V. G. Med. Chem. Res. 2004, 13, 325-336. doi:10.1007/s00044-004-0038-2

11. Chaniyara, R.; Kapuriya, N.; Dong, H.; Lee, P.-C.; Suman, S.; Marvania, B.; Chou, T.-C.; Lee, T.-C.; Kakadiya, R.; Shah, A.; Su, T.-S. Bioorg. Med. Chem. 2011, 19, 275-286.

doi:10.1016/j.bmc.2010.11.030

12. Wright, C. W.; Marshall, S. J.; Russell, P. F.; Anderson, M. M.; Phillipson, J. D.; Kirby, G. C.; Warhurst, D. C.; Schiff, P. L., Jr. J. Nat. Prod. 2000, 63, 1638-1640. doi:10.1021/np000144r

13. Gabrielsen, B.; Monath, T. P.; Huggins, J. W.; Kefauver, D. F.; Pettit, G. R.; Groszek, G.; Hollingshead, M.; Kirsi, J. J.; Shannon, W. M.; Schubert, E. M.; DaRe, J.; Ugarkar, B.; Ussery, M. A.; Phelan, M. J. J. Nat. Prod. 1992, 55, 1569-1581. doi:10.1021/np50089a003

14.Peterson, K. E.; Cinelli, M. A.; Morrell, A. E.; Mehta, A.; Dexheimer, T. S.; Agama, K.; Antony, S.; Pommier, Y.; Cushman, M. J. Med. Chem. 2011, 54, 4937-4953. doi:10.1021/jm101338z

15. Dömling, A.; Ugi, I. Angew. Chem., Int. Ed. 2000, 39, 3168-3210. doi:10.1002/1521-3773(20000915)39:18<3168::AID-ANIE3168>3.0.CO ;2-U

16. Dömling, A. Chem. Rev. 2006, 106, 17-89. doi:10.1021/cr0505728

17. Zhu, J.; Bienaymé, H., Eds. Multicomponent Reactions; Wiley-VCH: Weinheim, Germany, 2005.

18. Koopmanschap, G.; Ruijter, E.; Orru, R. V. A. Beilstein J. Org. Chem. 2014, 10, 544-598. doi:10.3762/bjoc. 10.50

19. Rotstein, B. H.; Zaretsky, S.; Rai, V.; Yudin, A. K. Chem. Rev. 2014, 114, 8323-8359. doi:10.1021/cr400615v

20. Bienaymé, H.; Hulme, C.; Oddon, G.; Schmitt, P. Chem. - Eur. J. 2000 , 6, 3321-3329. doi:10.1002/1521-3765(20000915)6:18<3321::AID-CHEM3321>3.0.C O;2-A

21. Wess, J.; Urmann, M.; Sickenberger, B. Angew. Chem., Int. Ed. 2001, 40, 3341-3350. doi:10.1002/1521-3773(20010917)40:18<3341::AID-ANIE3341>3.0.CO ;2-D

22. Koszytkowska-Stawińska, M.; Buchowicz, W. Beilstein J. Org. Chem. 2014, 10, 1706-1732. doi:10.3762/bjoc.10.179

23. Haji, M. Beilstein J. Org. Chem. 2016, 12, 1269-1301. doi:10.3762/bjoc.12.121

24. Hulme, C.; Ayaz, M.; Martinez-Ariza, G.; Medda, F.; Shaw, A. Recent Advances in Multicomponent Reaction Chemistry: Applications in Small Molecule Drug Discovery. In Small Molecule Medicinal Chemistry: Strategies and Technologies; Czechtizky, W.; Hamley, P., Eds.; Wiley-VCH: Weinheim, Germany, 2015; pp 145-187. doi:10.1002/9781118771723.ch6

25. Dömling, A.; Wang, W.; Wang, K. Chem. Rev. 2012, 112, 3083-3135. doi:10.1021/cr100233r

26. Akritopoulou-Zanze, I. Curr. Opin. Chem. Biol. 2008, 12, 324-331. doi:10.1016/j.cbpa.2008.02.004

27. Weber, L. Curr. Med. Chem. 2002, 9, 2085-2093. doi:10.2174/0929867023368719

28. Ugi, I.; Steinbrückner, C. Angew. Chem. 1960, 72, 267-268. doi:10.1002/ange.19600720709

29. Touré, B. B.; Hall, D. G. Chem. Rev. 2009, 109, 4439-4486. doi:10.1021/cr800296p

30. Bauer, S. M.; Armstrong, R. W. J. Am. Chem. Soc. 1999, 121, 6355-6366. doi:10.1021/ja9811243

31. Zhu, J. Eur. J. Org. Chem. 2003, 1133-1144. doi:10.1002/ejoc. 200390167 
32. Lu, K.; Luo, T.; Xiang, Z.; You, Z.; Fathi, R.; Chen, J.; Yang, Z. J. Comb. Chem. 2005, 7, 958-967. doi:10.1021/cc050099b

33. Lee, D.; Sello, J. K.; Schreiber, S. L. Org. Lett. 2000, 2, 709-712. doi:10.1021/ol005574n

34. Ramazani, A.; Rezaei, A. Org. Lett. 2010, 12, 2852-2855. doi:10.1021/ol100931q

35. Wang, W.; Ollio, S.; Herdtweck, E.; Dömling, A. J. Org. Chem. 2011, 76, 637-644. doi:10.1021/jo102058s

36. Groebke, K.; Weber, L.; Mehlin, F. Synlett 1998, 661-663. doi:10.1055/s-1998-1721

37. Blackburn, C.; Cuan, B.; Fleming, P.; Shiosaki, K.; Tsai, S. Tetrahedron Lett. 1998, 39, 3635-3638. doi:10.1016/S0040-4039(98)00653-4

38. Bienaymé, H.; Bouzid, K. Angew. Chem., Int. Ed. 1998, 37, 2234-2237. doi:10.1002/(SICI)1521-3773(19980904)37:16<2234::AID-ANIE2234>3 .0.CO;2-R

39. Kruithof, A.; Ruijter, E.; Orru, R. V. A. Chem. - Asian J. 2015, 10 , 508-520. doi:10.1002/asia.201403207

40. Hulme, C.; Lee, Y.-S. Mol. Diversity 2008, 12, No. 1. doi:10.1007/s11030-008-9072-1

41. Devi, N.; Rawal, R. K.; Singh, V. Tetrahedron 2015, 71, 183-232. doi:10.1016/j.tet.2014.10.032

42. Shaaban, B.; Abdel-Wahab, B. F. Mol. Diversity 2016, 20, 233-254. doi:10.1007/s11030-015-9602-6

43. Che, C.; Xiang, J.; Wang, G.-X.; Fathi, R.; Quan, J.-M.; Yang, Z. J. Comb. Chem. 2007, 9, 982-989. doi:10.1021/cc070058a

44. Che, C.; Li, S.; Jiang, X.; Quan, J.; Lin, S.; Yang, Z. Org. Lett. 2010, 12, 4682-4685. doi:10.1021/ol1020477

45. Che, C.; Li, S.; Yu, Z.; Li, F.; Xin, S.; Zhou, L.; Lin, S.; Yang, Z. ACS Comb. Sci. 2013, 15, 202-207. doi:10.1021/c0400001h

46. Che, C.; Yang, B.; Jiang, X.; Shao, T.; Yu, Z.; Tao, C.; Li, S.; Lin, S. J. Org. Chem. 2014, 79, 436-440. doi:10.1021/jo4024792

47. Yang, B.; Tao, C.; Shao, T.; Gong, J.; Che, C. Beilstein J. Org. Chem. 2016, 12, 1487-1492. doi:10.3762/bjoc.12.145

48. Xiang, J.; Yang, H.; Che, C.; Zou, H.; Yang, H.; Wei, Y.; Quan, J.; Zhang, H.; Yang, Z.; Lin, S. PLoS One 2009, 4, e4361. doi:10.1371/journal.pone.0004361

49. Guchhait, S. K.; Chaudhary, V.; Madaan, C. Org. Biomol. Chem. 2012, 10, 9271-9277. doi:10.1039/c2ob26733k

50. Chavignon, O.; Raihane, M.; Deplat, P.; Chabard, J. L.; Gueiffier, A.; Blache, Y.; Dauphin, G.; Teulade, J. C. Heterocycles 1995, 41, 2019-2026. doi:10.3987/COM-95-7126

51. Miaskiewicz, S.; Gaillard, B.; Kern, N.; Weibel, J.-M.; Pale, P.; Blanc, A. Angew. Chem., Int. Ed. 2016, 55, 9088-9092. doi:10.1002/anie.201604329

52. Mirabdolbaghi, R.; Dudding, T. Org. Lett. 2015, 17, 1930-1933. doi:10.1021/acs.orglett.5b00617

\section{License and Terms}

This is an Open Access article under the terms of the Creative Commons Attribution License

(http://creativecommons.org/licenses/by/4.0), which permits unrestricted use, distribution, and reproduction in any medium, provided the original work is properly cited.

The license is subject to the Beilstein Journal of Organic Chemistry terms and conditions:

(http://www.beilstein-journals.org/bjoc)

The definitive version of this article is the electronic one which can be found at:

doi:10.3762/bjoc. 13.82 